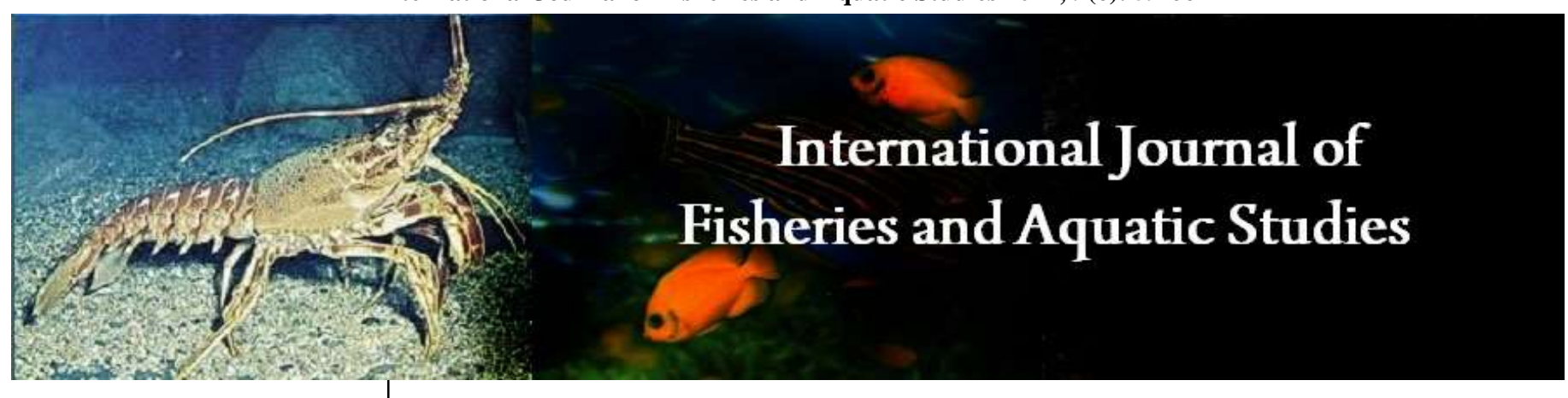

E-ISSN: 2347-5129

P-ISSN: 2394-0506

(ICV-Poland) Impact Value: 5.62

(GIF) Impact Factor: 0.549

IJFAS 2021; 9(6): 59-66

(C) 2021 IJFAS

www.fisheriesjournal.com

Received: 23-09-2021

Accepted: 27-10-2021

Mohd. Adip Setiawan

Department of Marine Science,

Postgraduate, Bogor

Agricultural University, Bogor,

West Java, Indonesia

Neviaty P Zamani

Department of Marine Science and Technology, Bogor

Agricultural University, Bogor,

West Java, Indonesia

Dietriech G Bengen

Department of Marine Science and Technology, Bogor

Agricultural University, Bogor,

West Java, Indonesia

Syofyan Roni

Workshop of Pekanbaru

National Water Conservation

Area, Ministry of Marine Affairs and Fisheries, Pekanbaru, Riau, Indonesia

Corresponding Author: Mohd. Adip Setiawan

Department of Marine Science,

Postgraduate, Bogor

Agricultural University, Bogor,

West Java, Indonesia

\section{Reef fish community structure and its association with Lifeform coral in the core zone of the Anambas islands Marine Tourism Park (MTP)}

\author{
Mohd. Adip Setiawan, Neviaty $P$ Zamani, Dietriech $G$ Bengen and \\ Syofyan Roni
}

DOI: https://doi.org/10.22271/fish.2021.v9.i6a.2587

\begin{abstract}
Reef fish are one of the biotas that live in coral reef ecosystems, and their lives depend on the condition of coral reefs. Reef fish communities have a close relationship with coral reefs as their habitat. Collecting data on reef fish and coral growth forms using the underwater visual census (UVS) method and methods point intercept transect (PIT). The results of the identification of coral growth forms found 10 growth forms. The most abundant group of fish in the core zone waters of the Anambas Islands was the omnivorous group of fish found as many as $14,924 \mathrm{ind} / 250 \mathrm{~m}^{2}$. The uniformity index value is obtained by the criteria for a stable uniformity index. The cluster analysis results showed that the similarity index of $43 \%$ was found in three groups of entities. The correspondence analysis results found three groupings of reef fish based on their association with coral growth forms.
\end{abstract}

Keywords: Anambas islands, association with Lifeform Coral, core zone, reef fish

\section{Introduction}

Anambas Islands Regency is the outermost district which is composed of a group of small islands. In general, potential damage to habitat can occur on small islands, for example, damage to coral reef ecosystems. (Marasabessy et al. 2018) ${ }^{[26]}$. Management of marine conservation areas is needed to maintain the sustainability of coral reef ecosystems. Anambas Islands Regency has a Marine Tourism Park (MTP), which was established based on the Decree of the Minister of Marine Affairs and Fisheries Number 37 of 2014 concerning National Water Conservation Areas. One of the ecological potentials in the Anambas Islands MTP is the coral reef ecosystem and the various types of reef fish that live in it (LKKPN Pekanbaru 2014) ${ }^{[22]}$.

Ecosystems in coastal areas and scattered in small islands are coral reefs, coral reefs function as a spawning ground, nursery ground, and feeding ground for most fish (Bengen 2013) ${ }^{[6]}$. Reef fish are one of the biotas that live in coral reef ecosystems, and their lives are highly dependent on the condition of coral reefs (Rodonuwu et al. 2013) ${ }^{[37]}$. The biophysical roles of coral reef ecosystems are very diverse, including a place to live, shelter, foraging, and breeding for various marine biota, including reef fish (Mardasin et al. 2011) ${ }^{[27]}$. Coral reef ecosystems can lead to high fishery productivity (reef fish) with high economic value (Bengen 2013) ${ }^{[5]}$.

Reef fish communities have a close relationship with coral reefs as their habitat. It is essential to know the existence of reef fish communities on a reef, seeing their role and function naturally (Rondonuwu 2014) ${ }^{[38]}$. The concept of community plays a role in analyzing the condition of an aquatic environment. The composition and characteristics of the community are good indicators to show environmental conditions and the ecological status of fish communities related to ecosystem stability (Ungaro et al. 1998) ${ }^{[42]}$.

Reef fish are one of the groups of animals associated with coral reefs, and their presence is conspicuous and found in various micro-habitats on coral reefs (Muniaha et al. 2019) ${ }^{[28]}$. Reef fish live permanently and forage for food in coral reef areas so that if coral reefs are damaged or destroyed, reef fish will also lose their habitat (Rani et al. 2010) ${ }^{[36]}$. The form of coral reef growth is closely related to the reef fish that inhabit it. The abundance of reef fish is highly dependent on the condition of coral reefs and the complexity of the existing habitats in the ecosystem (Allen et al. 2003) ${ }^{[2]}$. 


\section{Materials and Methods}

\subsection{Time and Place}

This research will be conducted in August 2020 in the Anambas Archipelago MTP Core Zone (Figure 1). Locations
The selected location is the Anambas Islands MTP Core Zone. The core zone is an area that has a functional purpose of improving habitat and reef fish stocks, with regulations prohibiting harvesting activities.

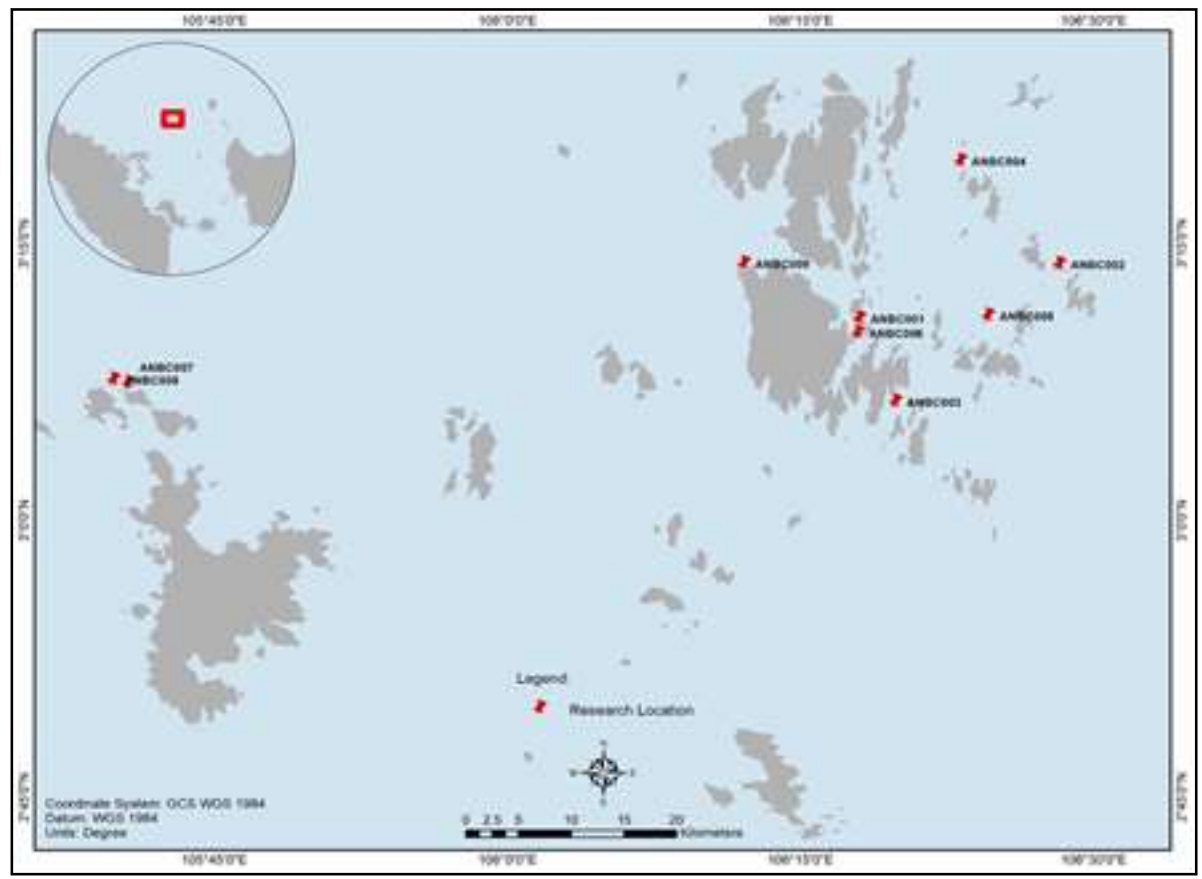

Fig 1: Sampling location in the core MTP zone of the Anambas Islands.

\subsection{Data Collection Methods Data}

The collection of reef fish species uses the method visual census (Dartnall and Jones 1986 in Rembet et al. 2011) ${ }^{[7,35],}$ a fast, accurate, effective, and environmentally friendly method. Benchmarks in data collection (following the technique Line Intercept Transect- LIT UNEP 1993) ${ }^{[43]}$. The data obtained are the number of species and the number of individuals of each species of fish. Reef fishes found inside the transect area were identified to the species level based on Kuiter and Tonozuka (2001) ${ }^{[20]}$, Allen et al. (2003) ${ }^{[2]}$ and Subhan et al. (2017) ${ }^{[40]}$.

The Poin intercept transect method (PIT) method measures sessile benthic cover, algae, and substrate type (hard coral, soft coral, sponge, and macroalgae) because it is fast, efficient, and provides a reasonable estimate of benthic community cover (Hill and Wilkinson 2004) ${ }^{[16]}$. Reef fish data were collected then analyzed to find data on species diversity, density (abundance). Furthermore, reef fish are grouped based on major fish, target fish, and indicator fish groups. The collection of reef fish data was followed by identifying reef fish groups based on trophic levels. It was found that four groups of reef fish were herbivores, carnivores, planktivores, and omnivores (Wibowo et al. 2016) [44].

Percentage cover calculates the percentage cover of each category of live coral and another benthic biota and abiotic category. The benthos categories calculated were LC: live coral (AC: Acropora and NA: Non-Acropora), DC: Dead coral, DCA: Dead coral with algae covering, SC: Soft coral, SP: Sponge, OT: Other fauna, R: Rubble, S: Sand, SI: Silt, RK: Rock. The percentage of cover for each category of coral reef growth forms was calculated using the formula according to English et al. (1997) ${ }^{[10]}$. The criteria for assessing the condition of coral reefs are based on the percentage of live coral cover (Kep. MENLH No. 4 2001) ${ }^{[19]}$.

\subsection{Analysis of Coral Fish Diversity and Its Association with Life form Coral}

Collected reef fish data were composition of reef fish species is grouped according to the classification of reef fish (major, indicator, and target). Reef fish communities have a close relationship with coral reefs as their habitat. The form of coral reef growth is closely related to the reef fish that inhabit it. The association of reef fish with coral reef growth forms in the Anambas Islands TWP core zone can be analyzed using correspondent analysis. The correspondent analysis is a multivariable analysis based on the row I matrix as the fish families found and column J matrix as coral growth forms in the Anambas Islands MTP core zone. Measurements to characterize the similarity are carried out by measuring the chi-square distance (Bengen 2000) ${ }^{[4]}$.

The level of grouping based on the similarity of reef fish species was used by the Bray-Curtis Index (Krebs 1989) ${ }^{[21]}$. The measurement of the Bray-Curtis similarity index can use the formula for the complement of the Bray-Curtis measurement index, which is 1.0-B (Krebs 1989) ${ }^{[21]}$. Data processing using software Primer-e7.

\section{Results and Discussion \\ 3.1 Composition of Growth Form and Percentage of Coral Reef Cover Coral reef}

Data collection at all observation stations was carried out in the core zone of the Anambas Islands MTP at a depth of 6-9.7 meters. Based on direct observations at the sampling site, it can be seen that, in general, the coral reefs in the Anambas Archipelago's MTP core zone grow from the reef flat to the edge. The identification of coral growth forms found 10 growth forms, consisting of two groups, namely Acropora and Non-Acropora, and Dead Sceleractinia, Algae, Abiotic and Other Fauna were found at the research station (Table 1). 
Table 1: Percentage of Coral Reef Cover.

\begin{tabular}{|c|c|c|c|c|c|c|}
\hline \multirow{2}{*}{ Station } & \multicolumn{9}{|c|}{ Category } \\
\cline { 2 - 7 } & Hard Corals & Dead Sceleractinia & Algae & Other Fauna & Abiotic & Category Conditions \\
\hline ANBC001 & 10 & 76 & 14 & 0 & 0 & Broken \\
\hline ANBC002 & 58 & 36 & 0 & 0 & 6 & Good \\
\hline ANBC003 & 20 & 50 & 0 & 8 & 22 & Broken \\
\hline ANBC004 & 42 & 16 & 0 & 0 & 42 & Moderate \\
\hline ANBC005 & 54 & 16 & 0 & 0 & 30 & Good \\
\hline ANBC006 & 22 & 66 & 0 & 0 & 12 & Broken \\
\hline ANBC007 & 60 & 28 & 0 & 0 & 12 & Good \\
\hline ANBC008 & 26 & 54 & 0 & 0 & 20 & Broken \\
\hline ANBC009 & 22 & 74 & 0 & 0 & 4 & Broken \\
\hline Percent Total (\%) & $\mathbf{3 4 , 8 9}$ & $\mathbf{4 6 , 2 2}$ & $\mathbf{1 , 5 6}$ & $\mathbf{0 , 8 9}$ & $\mathbf{1 6 , 4 4}$ & Moderate \\
\hline
\end{tabular}

The percentage of live coral cover found in the core zone of Anambas Island ranged from $10-60 \%$, with an average live coral cover of $34.89 \%$, which was categorized in moderate condition (Kep. MENLH No. 4 2001) ${ }^{[19]}$. Table 1 shows the highest percentage of live coral cover at stations ANBC 002 with a percentage of $58 \%$, ANBC 005 with a percentage of $54 \%$, and ANBC 007 with a percentage of $60 \%$. Based on the percentage of live coral cover, research stations ANBC 002, ANBC 005, and ANBC 007 can be classified in the excellent category. This good condition of coral reefs impacts the community in terms of fishing (Zamani 2015) ${ }^{[45]}$. The lowest percentage of live coral cover was found at the research station ANBC 001, with a percentage of $10 \%$ classified as damaged. The damaged category indicates that the coral reef ecosystem is in a state of distress or unfavorable condition. Coral reef ecosystems require more intensive management efforts to maintain the sustainability of coral reef ecosystems (Manembu et al. 2012) ${ }^{[25]}$.

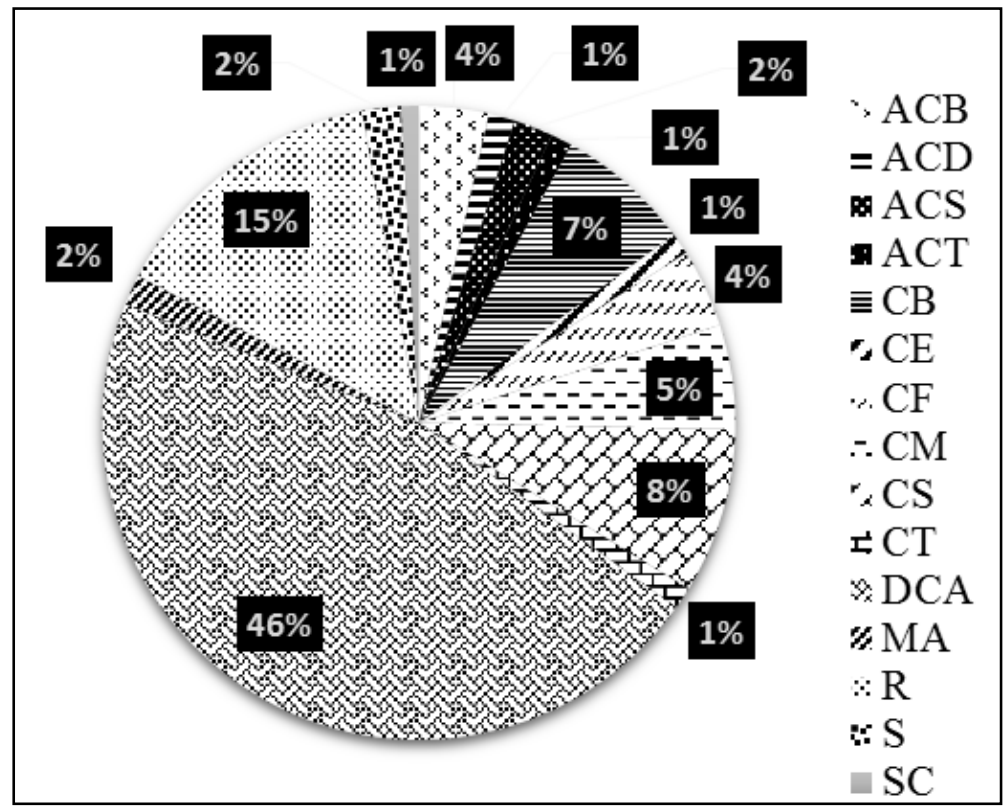

Fig 2: Percentage of coral reef growth forms in the core zone.

Figure 2 shows the highest percentage of hard coral growth forms in the core zone of the Anambas Islands MTP, namely CS with a coral cover percentage of $8 \%$, while the lowest percentage of hard coral growth forms is CT with a coral cover percentage of $1 \%$.

The growth forms most often found at each station were CB and $\mathrm{CM}$ growth forms. The growth forms of $\mathrm{CB}$ and $\mathrm{CM}$ are forms of growth that are commonly found in the core zone of the Anambas Islands. Massive corals mostly grow on the outer reefs with flowing waters, while branching corals are abundant along the edge of the reef and the top of the slopes, especially in protected or semi open waters (Johan 2003) ${ }^{[18]}$.

\subsection{Abundance, Trophic Levels of Reef Fish Based on Abundance of Coral Fish Groups}

The observations carried out in the waters of the MTP core zone of the Anambas Islands found 177 species of reef fish belonging to 33 families (Table 2). The composition of reef fish can be grouped into three groups, namely major fish groups, target fish groups, and indicator fish groups (English et al. 1997) ${ }^{[10]}$. 
Table 2: Total number reef fish subdistrict in MTP the Anambas Islands

\begin{tabular}{|c|c|c|c|c|c|c|c|c|c|}
\hline \multirow{2}{*}{ Family } & \multicolumn{9}{|c|}{ Research Station } \\
\cline { 2 - 11 } & $\begin{array}{c}\mathbf{A N B C} \\
\mathbf{0 0 1}\end{array}$ & $\begin{array}{c}\mathbf{A N B C} \\
\mathbf{0 0 2}\end{array}$ & $\begin{array}{c}\mathbf{A N B C} \\
\mathbf{0 0 3}\end{array}$ & $\begin{array}{c}\mathbf{A N B C} \\
\mathbf{0 0 4}\end{array}$ & $\begin{array}{c}\mathbf{A N B C} \\
\mathbf{0 0 5}\end{array}$ & $\begin{array}{c}\mathbf{A N B C} \\
\mathbf{0 0 6}\end{array}$ & $\begin{array}{c}\text { ANBC } \\
\mathbf{0 0 7}\end{array}$ & $\begin{array}{c}\text { ANBC } \\
\mathbf{0 0 8}\end{array}$ & $\begin{array}{c}\text { ANBC } \\
\mathbf{0 0 9}\end{array}$ \\
\hline Acanthuridae & 0 & 6 & 0 & 3 & 0 & 0 & 0 & 0 & 1 \\
\hline Apogonidae & 14 & 5 & 20 & 27 & 7 & 36 & 0 & 14 & 19 \\
\hline Aulostomidae & 0 & 0 & 0 & 0 & 0 & 0 & 0 & 0 & 1 \\
\hline Balistidae & 0 & 1 & 0 & 0 & 0 & 0 & 0 & 0 & 0 \\
\hline Caesionidae & 0 & 63 & 74 & 37 & 8 & 473 & 63 & 0 & 255 \\
\hline Carangidae & 0 & 3 & 4 & 0 & 0 & 0 & 0 & 0 & 5 \\
\hline Chaetodontidae & 6 & 23 & 29 & 20 & 40 & 24 & 6 & 4 & 32 \\
\hline Chanidae & 0 & 0 & 0 & 0 & 0 & 0 & 0 & 3 & 0 \\
\hline Engraulidae & 0 & 0 & 0 & 0 & 0 & 0 & 0 & 0 & 72 \\
\hline Ephippidae & 0 & 0 & 0 & 0 & 0 & 0 & 0 & 2 & 1 \\
\hline Gerreidae & 0 & 0 & 0 & 0 & 0 & 0 & 0 & 0 & 4 \\
\hline Gobiidae & 0 & 0 & 5 & 0 & 0 & 0 & 0 & 0 & 0 \\
\hline Grammistidae & 0 & 0 & 0 & 0 & 0 & 0 & 0 & 0 & 2 \\
\hline Haemulidae & 0 & 2 & 0 & 0 & 0 & 0 & 0 & 0 & 4 \\
\hline Holocentridae & 0 & 0 & 4 & 0 & 0 & 0 & 0 & 0 & 10 \\
\hline Labridae & 38 & 166 & 291 & 259 & 383 & 168 & 142 & 168 & 104 \\
\hline Lethrinidae & 0 & 0 & 10 & 0 & 9 & 0 & 0 & 0 & 0 \\
\hline Lutjanidae & 4 & 18 & 26 & 8 & 6 & 21 & 2 & 3 & 11 \\
\hline Monacanthidae & 8 & 0 & 0 & 0 & 0 & 0 & 0 & 0 & 0 \\
\hline Mullidae & 0 & 2 & 9 & 0 & 0 & 0 & 0 & 0 & 4 \\
\hline Muraenidae & 0 & 0 & 0 & 1 & 0 & 0 & 0 & 3 & 0 \\
\hline Nemipteridae & 0 & 2 & 25 & 17 & 36 & 19 & 0 & 15 & 16 \\
\hline Pomacanthidae & 15 & 4 & 28 & 10 & 15 & 10 & 16 & 10 & 45 \\
\hline Pomacentridae & 544 & 1101 & 1819 & 2149 & 3040 & 2392 & 1427 & 926 & 1464 \\
\hline Pseudochromidae & 2 & 0 & 0 & 0 & 0 & 2 & 0 & 0 & 1 \\
\hline Ptereleotrididae & 0 & 0 & 0 & 11 & 0 & 2 & 0 & 5 & 0 \\
\hline Scaridae & 121 & 74 & 310 & 431 & 253 & 166 & 88 & 170 & 172 \\
\hline Scorpaenidae & 0 & 0 & 0 & 0 & 0 & 0 & 0 & 0 & 1 \\
\hline Serranidae & 1 & 4 & 6 & 5 & 9 & 3 & 6 & 2 & 8 \\
\hline Siganidae & 0 & 10 & 11 & 672 & 10 & 12 & 5 & 12 & 2 \\
\hline Synodontidae & 0 & 3 & 0 & 2 & 4 & 0 & 0 & 0 & 0 \\
\hline Tetraodontidae & 1 & 0 & 0 & 0 & 0 & 0 & 0 & 0 & 1 \\
\hline Zanclidae & 0 & 0 & 0 & 0 & 0 & 0 & 0 & 0 & 17 \\
\hline
\end{tabular}

The composition of the most diverse fish families observed in the Anambas Islands MTP is presented in Table 2. The most abundant fish family in the Anambas Islands MTP is the Pomacentridae family, followed by the Scaridae. Overall, the most diverse families in the reef community were Pomacentridae and Labridae (Madduppa et al. 2013) ${ }^{[24]}$ Based on the trophic levels, reef fish have four trophic levels, namely omnivores, herbivores, planktivores, and carnivores.

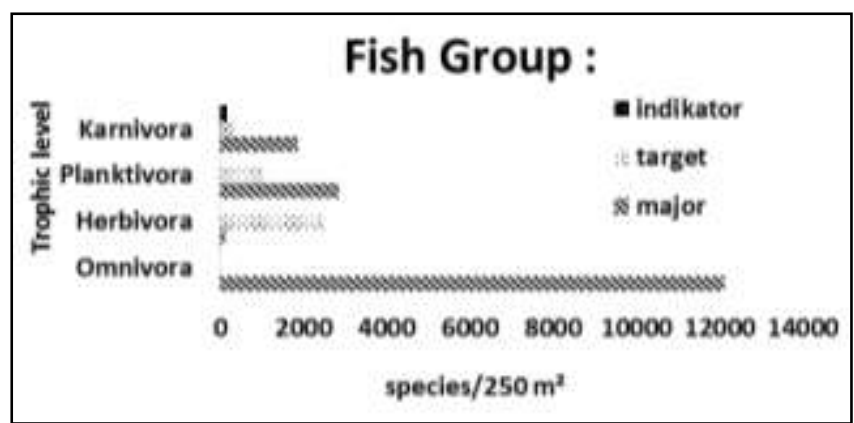

Fig 3: Reef fish trophic levels based on the abundance of reef fish groups.

Figure 3 shows the results of observations of the abundance of major fish groups as many as 108 reef fish species from 19 families with an abundance of $16,995 \mathrm{ind} / 250 \mathrm{~m}^{2}$. The highest major fish family was dominated by the Labridae, Pomacentridae, Pomacanthidae, and Apogonidae fish family.
Major fish groups are generally found in abundance, both in the number of individuals and types, and territorial. Major fish groups have a trophic level that omnivorous fish groups dominate with an abundance of reef fish species found as much as $12,132 \mathrm{ind} / 250 \mathrm{~m}^{2}$. The highest group of omnivorous fish was found from the fish family Pomacentridae. The Pomacentridae family is one of the most common inhabitants of coral reefs and is a key species in coral reef ecosystems (Hixon and Brostoff 1996; Paulangan et al. 2019) ${ }^{[17,33] .}$

The abundance of target fish groups was 61 reef fish species from 17 families with an abundance of $3,877 \mathrm{ind} / 250 \mathrm{~m}^{2}$. The Caesionidae, Lutjanidae, Nemipteridae, Scaridae, Serranidae, and Siganidae fish families dominated the highest target fish family. Under normal conditions, the target fish group can be found in tropical coral waters as much as $30 \%$ of the species that can live on coral reefs (Edrus et al. 2013) ${ }^{[8]}$. The target fish group had a trophic level dominated by $2,499 \mathrm{ind} / 250 \mathrm{~m}^{2}$ herbivorous fish groups, $1,045 \mathrm{ind} / 250 \mathrm{~m}^{2}$ planktivorous fish groups, and $333 \mathrm{ind} / 250 \mathrm{~m}^{2}$ carnivorous fish groups. High pressure on reef fishing indicates a decline in target fish catch groups. The target fish species include the fish families Serranidae, Lutjanidae, Lethrinidae, Nemipteridae, Caesionidae, Siganidae, Haemulidae, Scaridae and Acanthuridae (Paulangan et al. 2019) ${ }^{[33]}$.

The abundance of indicator fish groups was 11 reef fish species from the Chaetodontidae family, with an abundance of $184 \mathrm{ind} / \mathrm{m}^{2}$. The dominant indicator fish species were Chaetodon baronessa, Chaetodon octofasciatus and 
Chaetodon lunulatus. The indicator fish group has a trophic level dominated by carnivorous fish groups with an abundance of reef fish species found as much as $184 \mathrm{ind} / \mathrm{m}^{2}$. The existence of Chaetodontidae fish species indicates that the percentage of live coral cover is still in relatively good condition because Chaetodontidae fish species are indicators of coral reef health (Panggabean 2012) ${ }^{[32]}$. The indicator fish group is sporadic, at least one species of the indicator fish group is found in each research station.

\subsection{Coral Fish Association with Lifeform Coral Reef}

Results of correspondence analysis were conducted by looking at the relationship between the two main groups of reef fish families and coral reef growth forms, which are presented on two axes, namely the F1 axis and the F2 axis, with total diversity of $72.57 \%$. The correspondence analysis results found three groupings of reef fish based on their association with coral growth forms.

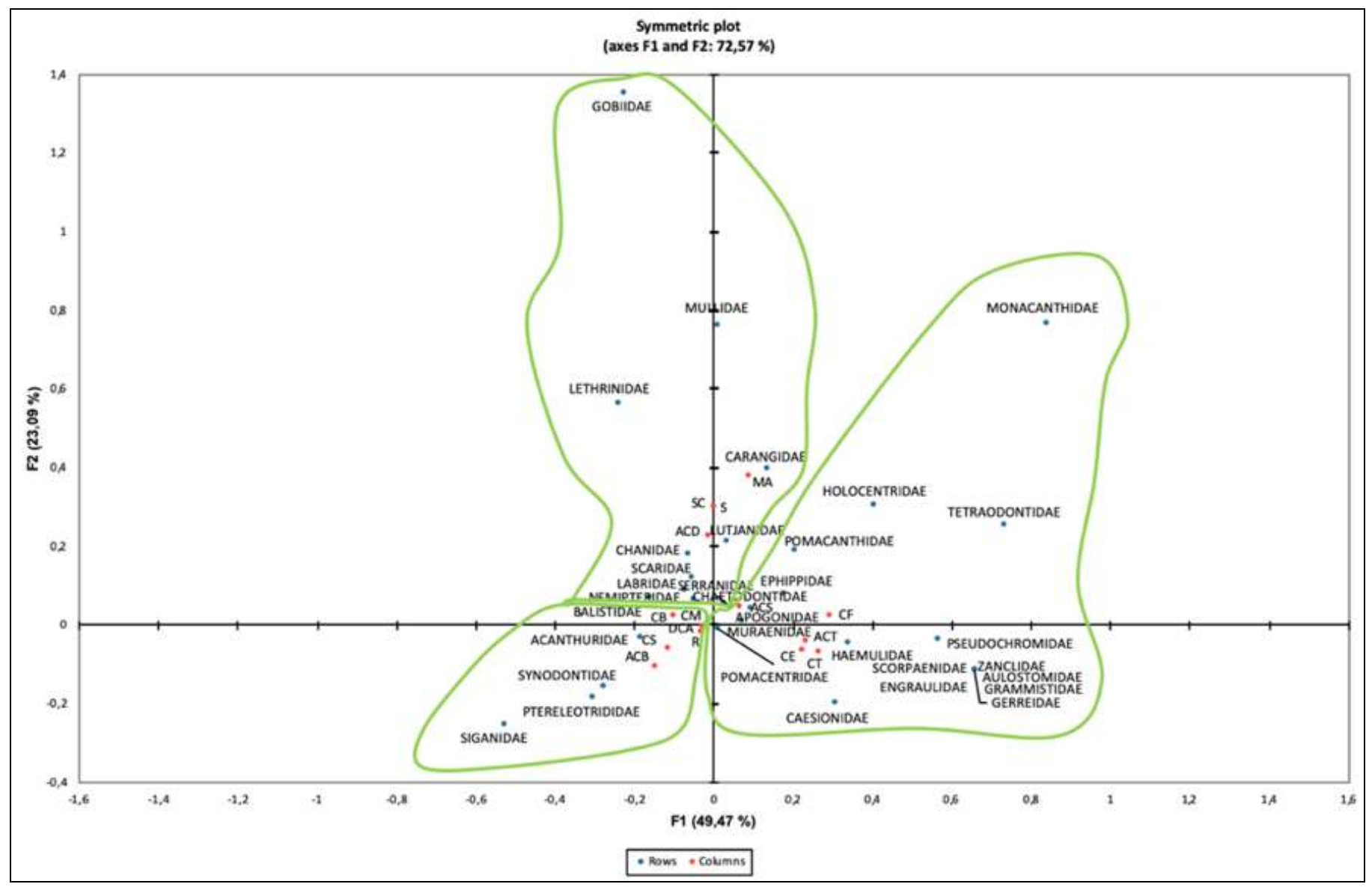

Fig 5: Correspondence analysis based on the association of reef fish families with coral growth forms.

Figure 5 shows the results of the correspondent analysis carried out on three groups of reef fish based on their association with coral growth forms. Group 1 consists of Apogonidae, Aulostomidae, Caesionidae, Engraulidae, Aphippidae, Gerreidae, Grammistidae, Haemulidae, Holocentidae, Monacanthidae, Muraenidae, Pomacanthidae, Pomacentridae, Pseudochromidae, Scorpaenidae, Tetraodontidae and Zanclidae, growth forms closely associated with ACS, CE, CF, and CT. The reef fish distribution is also influenced by the shape of coral reef growth, such as the Caesionidae fish, which prefer massive folios and submassive corals (Harsindhi et al. 2020; Faricha et al. 2020) ${ }^{[15,11]}$. The family group Caesionidae was found in clusters (schooling) in the direction of the water's edge. The association of fish of the Caesionidae family with the growth form of $\mathrm{CE}$ is caused by the availability of large space in the water column. The presence of the $\mathrm{CE}$ growth form makes it easier for yellowtail fish to get food because many of the biota (plankton) either surviving or settling on the coral can all be seen (Nnggajo et al. 2009) ${ }^{[30]}$.

Group 2 consisting of fish families Acanthuridae, Balistidae, Ptereleotrididae, Siganidae, and Synodonthidae, which are closely associated with coral reef growth forms ACB, CB, CM, CS, DCA, and R. The fish family Siganidae belongs to the trophic level of the herbivorous group. Herbivorous fish groups are one of the fish groups that play an important role in maintaining coral reef systems because they affect the growth and diversity of algae and change the structure of reef fish communities (Thacker et al. 2000; Gobler et al. 2006; Edwards et al. 2014; Putra et al. 2015; Paulangan et al. 2019) $[41,14,9,34,33]$. The abundance of herbivorous fish was negatively correlated with the percentage of macroalgae cover but positively correlated with the addition of coral individuals/colonies (Mumby et al. 2006; Wibowo et al. 2016) ${ }^{[29,44]}$.

Group 3 consisting of fish families Carangidae, Chaetodontidae, Chanidae, Gobiidae, Labridae, Lethrinidae, Lutjanidae, Mullidae, Nemipteridae, Scaridae, and Serranidae, which are closely associated with coral reef growth forms ACD, MA, S, and SC. The relationship of the Chaetodontidae family group is closely related to the growth form of ACD coral reefs. Species Chaetodon unimaculatus prefers to eat coral polyps montiporid leaf shaped (Acroporidae) (Belland and Galzin 1984; Cox 1994; Luthfi et al. 2016) ${ }^{[3,6,23]}$. The indicator fish group was dominated byspecies Chaetodon octofasciatus. Fish species Chaetodon octofasciatus dominate in the waters and spread over all observation sites (Adrim et 
al. 2012) ${ }^{[1]}$. The existence of the Chaetodontiade fish family indicates that the percentage of live coral cover is still quite good because this type of fish is an indicator of coral reef health (Panggabean 2012) ${ }^{[32]}$. The presence of indicator fish illustrates that the ecological condition of coral reefs is still capable of being used as a habitat for reef fish.

\subsection{Classification of Clusters of Similarity and Multidimensional Scaling (MDS) Reef Fish}

The cluster analysis results showed a similarity index (similarity) of $43 \%$ found three groups of entities (habitats), namely groups $\mathrm{A}, \mathrm{B}$, and $\mathrm{C}$. This grouping showed differences in the composition of reef fish species between these groups (Setiawan 2016) ${ }^{[39]}$.

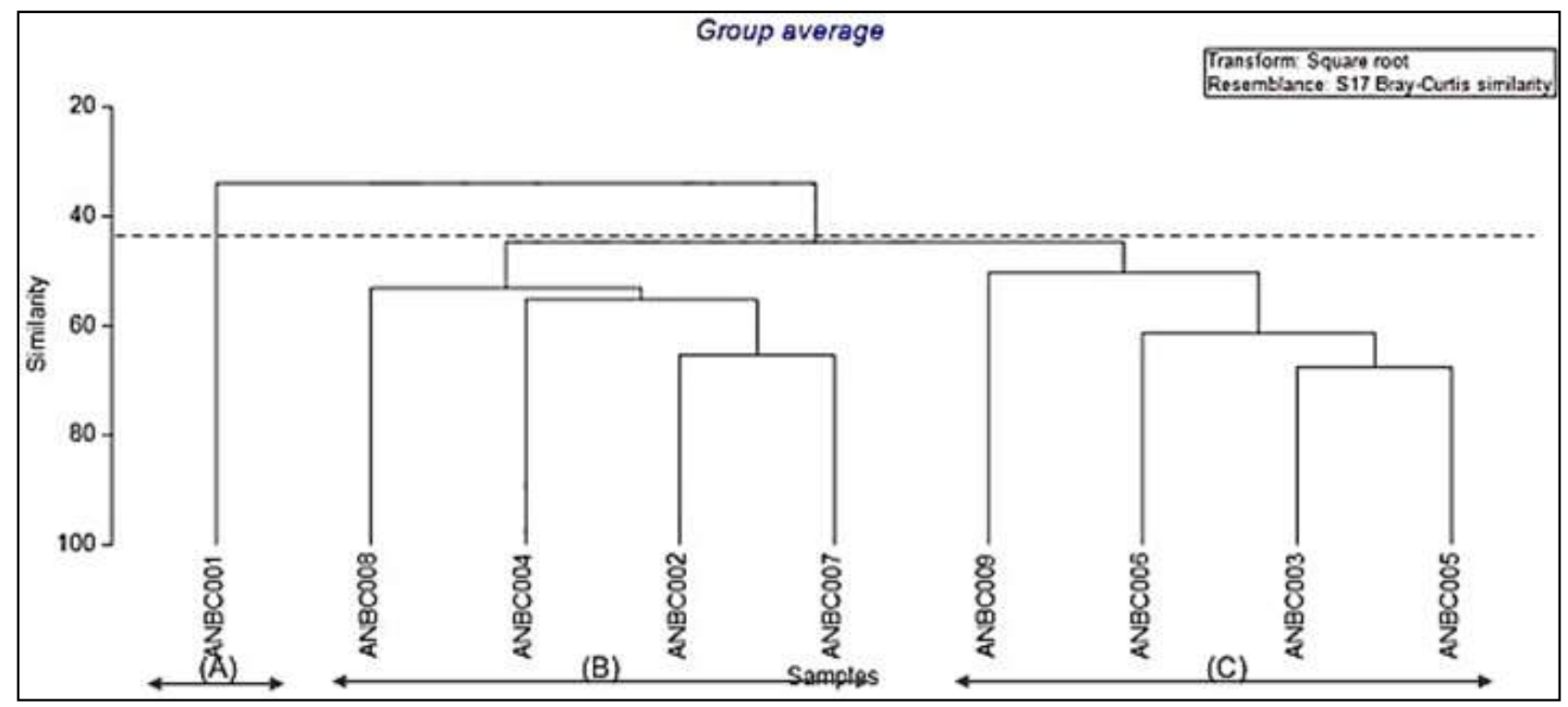

Fig 6: Results of cluster analysis based on the Bray-Curtis similarity index.

Figure 6 shows three groups, namely group A, B, and C. Group A consists of ANBC 001 station, research station ANBC 001 located east of the core zone of the Anambas Islands, a research station located in closed strait waters. Characteristics of semi-enclosed waters where the abundance of fish and coral is limited due to the limited circulation that enters the bay (Setiawan 2016) ${ }^{[39]}$. Group B consists of research stations ANBC 008, ANBC 004, ANBC 002, and ANBC 007 located to the east and west of the core zone of the Anambas Islands. Research stations ANBC 002 and ANBC 004 are located in the east, while research stations ANBC 007 and ANBC 008 are located in the west, having very far distanced between stations but having the exact resemblance to reef fish communities. Locations located quite far apart but pointing towards the outside of the waters have a community resemblance (Adrim et al. 2012) ${ }^{[1]}$. Group C consists of research stations ANBC 009, ANBC 006, ANBC 003, and ANBC 005 located to the east of the core zone of the Anambas Islands, between stations having similarities to reef fish communities. The research stations ANBC 003, ANBC 005, and ANBC 006 are located at a close distance. The proximity of the research sites causes the similarity of reef fish communities.

\section{Conclusion}

The highest abundance of fish species based on their trophic level in the core zone of the Anambas Islands MTP is an omnivore fish group. Reef fish species are evenly distributed and there is no dominance of one species over another. The condition of the reef fish found in the Anambas Islands TWP is in good condition. The cluster analysis showed that the similarity index (similarity) of $43 \%$ was found in three groups of entities (habitats). The correspondence analysis results found three groupings of reef fish based on their association with coral growth forms.

\section{Acknowledgements}

Authors would like to thank the Faculty of Fisheries and Marine Sciences, Department of Marine Sciences, Graduate School, Bogor Agricultural University. Pekanbaru National Water Conservation Area Workshop, Ministry of Maritime Affairs and Fisheries who has provided assistance and support for research facilities. The authors thank the reviewers for their valuable comments.

\section{References}

1. Adrim M, Harahap SA, Wibowo K. Struktur komunitas ikan karang di perairan Kendari. Jurnal Ilmu Kelautan 2012;17(3):154-163.

Https://Doi.Org/10.14710/IK.IJMS.17.3.154-163

2. Allen GR, Steene R, Humann P, Deloach N. Reef Fish Identification Tropical Pacific. Australia New World Publications, Australia 2003.

3. Bell JD, Galzin R. Influence of live coral cover on coralreef fish communities. Marine Ecology Progress Series 1984;15(2):265-274.

4. Bengen DG. Sinopisis Teknik Pengambilan Contoh dan Analisis Data Biofisik Sumberdaya Pesisir. Institut Pertanian Bogor, Bogor 2000.

5. Bengen DG. Bioekologi Terumbu Karang Status dan Tantangan Pengelolaan dalam Coral Governance. IPB Press Bogor 2013.

6. Cox EF. Resource use by corallivorous butterflyfishes (family chaetodontidae) in Hawaii. Bulletin of Marine Science 1994;54(2):535-545.

7. Dartnall AJ, Jones M. A Manual of survey Methods for Living Resources in Coastal Area. Australia Cooperation Program on Marine Science, Australia 1986.

8. Edrus IN, Wijaya SW, Setyawan IE. Struktur komunitas ikan karang di perairan pulau raya, pulau rusa, pulau rondo dan taman laut rinoi dan rubiah, nanggroe aceh 
darussalam. Jurnal Lit Perikanan 2013;19(4):175-186. Https://Doi.Org/10.15578/jppi.19.4.2013.175-186

9. Edwards CB, Friedlander AM, Green AG, Hardt MJ, Sala E, Sweatman HP, Williams ID, Zgliczynski B, Sandin SA, Smith JE. Global assessment of the status of coral reef herbivorous fishes: evidence for fishing effects. Proceeding Royal Sociaty B 2014.

10. English S, Wilkinson C, Baker V. Survey Manual for Tropical Marine Resources. Australia Institute of Marine Science, Australia 1997.

11. Faricha A, Edrus IN, Utama RS, Dzumalex AR, Salatalohi A, Prayuda B. Hubungan antara komposisi ikan target dan persentase tutupan karang hidup di kepulauan kei kecil, maluku. Jurnal Penelitian Perikanan Indonesia 2020;26(3):147-157. Https://Doi.Org/10.15578/jppi.26.3.2020.147-157

12. Fiel JG, Clarke KR, Warwick RM. Apractical strategy for analising multispecies distribution patterns. Mar Ecol Prog 1982;8:37-52.

13. Feary DA, McCormicl MI, Jones GP. Growth of reef fishes in response to live coral cover. Jurnal of Experimental Marine Biology and Ecology 2009;373(1):45-49. Https://Doi.Org/10.1016/j.jembe.2009.03.002

14. Gobler CJ, Thibault DB, Davis TW, Curran PB, Peterson BJ, Liddle LB. Algae assemblages associated with stegastes sp. Territories on indo-pasific coral reefs: characterization of diversity and controls on growth. Jurnal of Experimental Marine Biology and Ecology 2006;336(1):135-145.

Https://Doi.Org/10.1016/j.jembe.2006.04.012

15. Harsindhi CJ, Bengen DG, Zamani NP, Kurniawan F. Abundance and spatial distribution of reef fish base on coral lifeforms at tidung island, seribu island, jakarta bay. AACL Bioflux 2020;13(2):736-745.

16. Hill J, Wilkinson C. Methods for Ecological Monitoring of Coral Reefs. A Resources for Managers. Australian Institute of Marine Science, Australia 2004.

17. Hixon MA, Brostoff WN. Succession and Herbivory : Effects of Defferential Fish Grazing on Hawaiian CoralReef Algae. Eco Society of America 1996;66(1):67-90.

18. Johan O. Metode Survey Terumbu Karang Indonesia. Yayasan Terangi, Jakarta 2003.

19. Keputusan Kementrian Lingkungan Hidup No. 4 tahun tentang Kreteria Baku Kerusakan Terumbu karang. Kementrian Lingkungan Hidup, Jakarta 2001.

20. Kuiter RH, Tonozuka T. Pictorial Guide to Indonesian Reef Fishes, part 1-4 (AU). Zoonetics. Australia 2001.

21. Krebs Ch J. Ecological Methodology (COL). Univ of British Columbia Harper Collins Publisher, Columbia 1989.

22. Loka Kawasan Konservasi Perairan Nasional Pekanbaru. Zonasi TWP Kepulauan Anambas dan Laut Sekitarnya.Kawasan TWP Kepulauan Anambas dan Laut sekitarnya potensi ekologi, potensi ekonomi dan potensi sosial budaya. Loka Kawasan Konservasi Perairan Nasional Pekanbaru, Pekanbaru 2014.

23. Luthfi OM, Pujarahayu P, Fajar KS, Wahyudiarto A, Fakri SR, Sofyan M, Ramadhan F, Ghofur MAA, Murian S, Tovani I, Mahmud, Adi D, Abdi F. Biodiversitas dan populasi ikan karang di perairan selat sempu sendang biru kabupaten malang jawa timur. Jurnal Kelautan Indonesia 2016;9(1):43-49.
24. Madduppa HH, Subhan B, Suparyani E, Siregar AM, Arafat D, Tarigan SA, et al. Dynamics of fish diversity across an environmental gradient in the seribu islands reefs off Jakarta. Biodiversitas 2013;14(1):17-24. Https://Doi.Org/10.13057/biodiv/d140103

25. Manembu I, Adrianto L, Bengen DG, Yulianda F. Distribusi karang dan ikan karang di kawasan reef ball teluk buyat kabupaten minahsa tenggara. Jurnal Perikanan dan Kelautan Tropis 2012;8(1):28-32. Https://Doi.Org/10.35800/jpkt.8.1.2012.342

26. Marasabessy I, Fahrudin A, Imran Z, Agus SB. Strategi pengelolaan berkelanjutan pesisir dan laut pulau nusa manu dan pulau nusa leun di kabupaten maluku tengah. Journal of Regional and Rural Development Planning 2018;2(1):1-22. Https://Doi.Org/10.29244/jp2wd.2018.2.1.11-22

27. Mardasin W, Ulqodry TZ, Fauziyah. Studi keterkaitan ikan karang dengan kondisi karang tipe acropora di perairan sidodadi dan pulau tegal, teluk lampung keb. pesawaran, provinsi lampung. Maspari Journal 2011;03:42-50.

Https://Doi.Org/10.36706/maspari.v3i2.1318

28. Muniaha H, Nur AI, Rahmadanu. Studi kelimpahan ikan karang berdasarkan kondisi terumbu karang di desa tanjung tiram kabupaten konawe selatan. Jurnal Manajemen Sumber Daya Perairan 2019;2(1):9-19.

29. Mumby PJ, Dahlgren CP, Harborne AR, Keppel CV, Micheli F, Brumbaugh DR, et al. Fishing, trophic cascades, and the prosess og grazing on coral reefs. Science 2006;311(5757):98-101. Https://Doi.Org/10.1126/science.1121129

30. Nggajo R, Wardiatno Y, Zamani NP. Keterkaitan sumberdaya ikan ekor kuning (caesio cuning) dengan karakteristik habitat pada ekosistem terumbu karang di kepulauan seribu. Jurnal Ilmu-Ilmu Perairan dan Perikanan Indonesia 2009;16(2):97-109.

31. Nybakken JW. Biologi Laut, Suatu Pendekatan Ekologis. PT. Gramedia Pustaka Utama, Jakarta 1992.

32. Panggabean AS. Keanekaragaman jenis ikan karang dan kondisi kesehatan karang di pulau gof kecil dan yep nabi kepulauan raja ampat. Jurnal Lit Perikanan 2012;18(2):109-115.

33. Paulangan YP, Fahrudin A, Sutrisno D, Bengen DG. Keanekaragaman dan kemiripan bentuk profil terumbu berdasarkan ikan karang dan lifeform karang di teluk depapre jayapura, provinsi papua, Indonesia. Jurnal Ilmu dan Teknologi Kelautan Tropis 2019;11(2):249-262. Https://Doi.Org/10.29244/jitkt.v11i2.24140

34. Putra MIH, Afatta S, Wilson J, Muljadi A, Yusidarta I. Coral reef resilience in 17 islands marine recreation park, ruiungan assessment of fungtional groups of herbivorous fish and benthic substrate. Procedia Eviromental Sciences 2015;23:230-239.

Https://Doi.Org/10.1016/j.proenv.2015..01.035

35. Rambet UN, Boer M, Bengen DG, Fahrudin A. Struktur komunitas ikan target di terumbu karang pulau hogow dan putus-putus, sulawesi utara. Jurnal Perikanan dan Kelautan Tropis 2011;7(2):1-6. Https://Doi.Org/10.35800/jpkt.7.2.2011.179

36. Rani C, Burhanuddin AI, Atjo AA. Sebaran dan Keanekaragaman Ikan Karang di Pulau Barrangloppo: Kaitannnya Dengan Kondisi dan Kompleksitas Habitat. Fakultas Kelautan dan Imu Kelautan Universitas Hasanuddin, Makassar 2010. 
37. Rondonuwu AB, Rembet UN, Moningkey RDJ, Tombokan JL, Kambey AD, Wantasen AS. Coral fishes the famili chaetodontidae in coral reef waters of para island sub district tatoareng, sangihe kepulauan regency. Jurnal Ilmiah Platax 2013;1(4):210-215. Https://Doi.Org/10.35800/jip.1.4.2013.3705

38. Rondonuwu AB. Ikan karang di wilayah terumbu karang kecamatan maba kabupaten halmahera timur provinsi maluku utara. Jurnal Ilmiah Platax 2014;2(1):1-7. Https://Doi.Org/10.35800/jip.2.1.2014.4403

39. Setiawan F. Komunitas ikan karang di perairan taman wisata alam batuangus, kotamadya bitung, provinsi Sulawesi utara. Jurnal Kelautan 2016;9(1):50-61. Https://Doi.Org/10.21107/jk.v9i1.1032

40. Subhan B, Khair M, Madduppa H, Nurjaya IW, Ardiwijaya RL, Prabuning D, et al. Terumbu Karang Tulamben.IPB Press, Bogor 2017.

41. Thacker RW, Gunsburg DW, Paul VJ. Effects of herbivore exclusion and nutrient enrichment on coral reef macroalgae and cyanobacteria. Coral Reefs 2001;19(4):318-329. $10.1007 / \mathrm{s} 003380000122$

Https://Doi.Org/

42. Ungaro N, Marano G, Marsan R. Demersal fish asssemblages biodiversity as an index of fishery resources exploitation. Italian Journal Zoology 1998;65:551-516.

43. United Nation Environmental Program. Monitoring Coral Reefs For Global Change. Regional Seas. Reference Methods ForMarine Pollution Studies 61. Australian Institute Of Marine Science, Australian 1993.

44. Wibowo K, Abrar M, Siringoringo RM. Status trofik ikan karang dan hubungan ikan herbivora dengan rekrutmen karang di perairan pulau pari, teluk Jakarta. Jurnal Oseanologi dan Limnologi di Indonesia 2016;1(2):73-89. Https://Doi.Org/10.14203/oldi.2016.v1i2.85

45. Zamani N P. Kondisi terumbu karang dan asosiasinya dengan bintang laut (linckia laevigata) di perairan pulau tunda, kabupaten seram, provinsi banten. Jurnal Teknologi Perikanan dan Kelautan 2015;6(1):1-10. Https://Doi.Org/10.24319/jtpk.6.1-10. 